\title{
On the Translation of Children's Literature
}

\author{
Yu Zhang \\ School of Foreign Languages, Qingdao University of Science and Technology, Qingdao, China \\ Email: zhangyu_qust@163.com
}

\begin{abstract}
This paper aims at exploring the history of the translation of the children's literature in the four periods, that is, the late Qing Dynasty and the early Republican China, the May Fourth period, the Anti-Japanese War period, and the period after 1976, and finds that each period has its own characteristics in the translations. The paper also studies some strategies that the translators usually adopt and illustrates the accordant merits.
\end{abstract}

Index Terms - children's literature, translation, domestication, foreignization, strategies

\section{INTRODUCTION}

Children's literature is a generic term of literary works written according to children's psychology and ability of reading on three levels: preschoolers' literature, children's literature and youth's literature.

As a result of society's concept of childhood, children's literature, unlike adult literature, is considered an important vehicle for achieving certain aims in the education of children. Therefore in translating the children's literature, the translators usually manipulate the original texts to some extent with the intention of serving different purposes. Accordingly, from the very beginning up till now, the translations of children's literature in China have different characteristics.

\section{ChaRACTERISTICS}

\section{A. Translations of the Children's Literature in the Late Qing Dynasty and the Early Republican China}

According to the statistics by some scholars, there were about 120 translations, 59 translators, 18 publishing companies and 29 magazines in this period. Most of the translations were translated from English and Japanese. The center of the translating was in Shanghai. The translations of the children's literature in this period have the following characteristics. First, the purpose of translating was to realize the revolution of novels. Translating was just a tool to reform the society. Secondly, in most of the translations, the target language was the ancient Chinese instead of modern Chinese. Thirdly, the translation method differed from person to person. For example, While Lin Shu deleted much scenario and phraseology, as a result of which his translations were not faithful to the original work, Zhou Zuo-ren and Zhou Gui-sheng took to literal translation and ancient Chinese to reflect the original style.

\section{B. Translations of the Children's Literature in the May Fourth Period}

In this period, many foreign works were translated in China, which were mainly of three kinds: folk tales and artistic tales, animal tales and fables, and some non-children literature fit for children's reading. Besides Lu Xun, Zhou Zuo-ren, Liang Shi-qiu, Xu Zhi-mo and other litterateurs began falling over themselves for the translation of children's literature. They aimed at publicizing science, love and beauty by expressing the intellectual's yearn for originality, honesty, nature and lively life.

More echoism and mimesis words were used in the translations of this period. The uncommon nouns had remarks; both literal translation and free translation were adopted though literal translation was more colloquially popular than free translation. Colloquialism had already replaced the classical Chinese so that children could read more conveniently. The translators paid attention to the way of translating, printing, decorative art and illustration with a view of children's personality and characteristics.

In the May-fourth movement period, children's literature translators accumulated rich experience through practice and made the children's literature turn to mature. Although the strategies of domestication and foreignization were in dispute, they played a positive role in the development of children's literature. No matter what kind of strategy was adopted, the translators reached a consensus that the translation should serve the children.

\section{Translations of the Children's Literature in the Anti-Japanese War Period}

According to Wen Jun and Wang Chen-shuang (2008), during the 14 years from September in 1931 to August in 1945, there were 369 translations of the children's literature, including 201 fairy tales, 143 children fiction and children stories, 12 fables, 9 pantomimes, 3 children poems, 1 theory book about the children's literature, etc. The counties concerned were mainly Soviet Russia, Britain and America.

The translations of this period had a great impact on expediting the Chinese children's literature.

a. The influence of children-oriented sense in the translated versions boosted the right understanding of Chinese 
traditional beliefs on children, and speeded the maturity and modernization of children literature style. The translators of this period were both earnest introducers and originators. Their creative practice was affected by the foreign children's literature directly or indirectly.

b. The children's literature of Soviet Russia greatly influenced Chinese modern children literature. The translations from the Soviet Russia did not only help Chinese children learn the new images of children in the new world, but also brought new effects to Chinese creative writing.

c. The translating and instructing enriched the style of modern Chinese children's literature. Modern Chinese children's literature draws lessons from foreign tales in thought, form and skills.

\section{Translations of the Children's Literature after 1976}

Since 1976, scholars and educationalists have changed their ideas of the purposes of children's literature. What the translators are concerned over is whether the children can understand the translations instead of the adults' willing or the educational function of the children's literature. They grant themselves great liberties regarding the text because of the polysystem and manipulate the text in various ways, as a result of which, the translations are children-oriented indeed.

In the 1980s, the translators paid much more attention to the strategy of foreignization, and reflected in the variety of translation practice. With the improvement of China's international status, the exchanges between China and other countries in the world become increasingly frequent, readers' thinking changed much. They held more open attitudes to the foreign languages and cultures. 1980s saw the upsurge of learning foreign languages and the strong impact of the foreign films, cartoons and translations of the children's books, one result of which was the capacity that Chinese children accepted western literature and culture greatly increased.

\section{STRATEGIES OF THE TRANSLATIONS}

Just as Shavit (1981) states, the translator of children's literature can permit him/herself great liberties regarding the text because of the peripheral position children's literature occupies in the polysystem, in translating the children's literature, the translators usually adopt the following strategies:

\section{A. Use of Lively and Interesting Language}

It is an important aim to make the children readers happy by producing and translating interesting versions. The translators resort to the changes in wording and sentence patterns. For example:

And she went on planning to herself how she would manage it. "They must go by the carrier," she thought; "and how funny it'll seem, sending presents to one's own feet! And how odd the directions will look! ...”

接着她自己就盘算起来, 怎样才能把靴子给它们送去。“一定得请邮递员送去, ”她想, “这看来多滑稽, 给自 己的脚送礼物！还有这姓名和地址也显得多奇怪！(translated by Chen Fu'an, p17)

In the translation, the two “ands” are turned respectively into “接着” and“还有”, which read more suitable than “而 且”; the passive voice is turned into action one, which is more acceptable in Chinese.

\section{B. Use of Simple and Colloquial Words}

Wording is a key point because usually one foreign word can be rendered into many different Chinese words. The children do not have great vocabulary or experience. Thereafter, the translator should take the children's ability of understanding and cognition into account, and use as simple and colloquial words as possible. For example,

"Not the same thing a bit!" said the Hatter. "Why, you might just as well say that 'I see what I eat' is the same thing as 'I eat what I see'!”

“压根儿不是一回事! ”帽匠说, “那样的话, 你倒满可以说“我吃的我都看见’和“我看见的我都吃”, 是一回 事! ”(translated by Chen Fu'an, p103)

The original is colloquial, and the translator uses colloquialism such as “压根儿”,“倒”and“满”etc. to reflect the vivid expression of the persona's characteristics.

\section{Use of Simple and Straightaway Sentence Patterns}

There are more long and complex sentences in the foreign literature than in Chinese literature, especially in children's literature. The translators usually transform the long and complex sentences into short and simple sentences in case that the children may lose the interest of reading. For example:

Alice was beginning to get very tired of sitting by her sister on the bank and of having nothing to do: once or twice she had peeping into the book her sister was reading, but it had no pictures or conversations in it, "and what is the use of a book," thought Alice, "without pictures or conversations?"

阿丽思和姐姐一起坐在河岸上, 没事可干, 坐得凨味了; 她向姐姐正看着的书瞄了一两眼, 可那上面没有图 画, 也没有对话。阿丽思想道: “一本书没有图画, 又没有对话, 那有什么用啊? ”(translated by Chen Fu'an, p3)

The original sentence is a very long one with 57 words; the Chinese translation turns it into 3 parts with 2 sentences, in which case the Chinese children can read the translation with great ease.

\section{Use of Interjections}


Interjections, a very special lexical category which have no sense of independent entity, are usually put at the end of the sentences, or the pause of the sentence, to show the speaker's tone and mood, and therefore endow the text with some additional feelings and emotions. The use of interjections mainly expresses the notion of the original text, the phatic function, and acts as a kind of cohesion device. Pragmatically, interjections are used to add some shade to the speaker's tone, or soften the tone of the speaker, make the subject prominent, propose the supposition and thus attract the listener's attention. Interjections can make the translations more vivid and readable for the young children. For example:

"My name," said the spider, "is Charlotte."

“我的名字嘛, ”那蜘蛛说, “叫夏洛。”（translated by Ren Rongrong, p186）

Down, down, down. Would the fall never come to an end?

掉啊, 掉啊, 掉啊! 这一跤怎么一辈子摔不完了吗! (translated by Zhao Yuanren, p7)

\section{E. Addition of Onomatopoeic Words}

In dealing with the children's books, the translators sometimes add onomatopoeic words to vividly reflect the children's language:

However, this bottle was not marked "poison," so Alice ventured to taste it, and finding it very nice,(it had, in fact, a sort of mixed flavour of cherry-tart, custard, pine-apple, roast turkey, toffy, and hot buttered toast,)she very soon finished it off.

然而这一回瓶子上并没有“毒药”的字样在上，所以阿丽思就大着胆子尝它一尝，那味儿倒很好吃（有点像樱 桃饼, 又有点像鸡蛋糕, 有点像菠萝蜜, 又有点像烤火鸡, 有点像冰淇淋, 又有点像芝麻酱), 所以一会儿工夫 就唏哩呼噜地喝完了。(translated by Zhao Yuanren, p16)

不过不管怎么说，这个瓶子并没有标明“有毒”，所以爱丽丝斗胆尝了一口，并且发现味道挺不错（事实上， 瓶子里的东西含有一种㭥桃馅饼、牛乳蛋糕、菠萝、烤火鸡、太妃糖, 以及热奶油烤面包片一起混合起来的味 道)，于是她咕嘟咕嘟一下子全喝光了。(translated by Wu Juntao, p11)

不过，这个瓶子上没有标着“毒药”的字样，所以爱丽丝就壮着胆子尝了一点儿。她觉得那味道很美，像是把 樱桃馅饼、奶油蛋糕、菠萝、烤火鸡、奶糖和热奶油面包的味道混合在一起似的。她很快就把它喝得精光。 (translated by Jia Wenhao and Jia Wenyuan, p8)

Compared with the last translation which does not have onomatopoeic words, the tone of the first two translations sounds more like that of the children, and therefore there is no doubt that the translations with onomatopoeic words have higher readability.

\section{F. Intercultural Transfer}

Eugene A. Nida holds that it is more important for a successful translator to acquaint him/herself with two cultures than to know two languages because the words achieve their meanings in their own cultural backgrounds. The translation of children's literature is no exception. There are two strategies in translating the cultural factors in children's literature: Foreignization and Domestication. The former requires that we reserve the original exoticism to make the readers know more about the source language and the culture. The latter caters to the target language and culture. Mostly translators apply the latter strategy in order that the children readers can understand the corresponding factors easily. Sometimes translators resort to the literal translation and then add some annotation. For example:

尤利西斯的归来（尤利西斯是古希腊荷马史诗《奥德修纪》中的一位大英雄)(translated by Ren Rongrong, p188)

优利西斯归来（优利西斯归来：故事出自古希腊荷马的史诗《奥德赛》。名将优利西斯在攻打特洛亚城胜利之 后乘船回家, 经过种种磨难, 终于回到家里, 惩治了以向他妻子求婚为名想霸占他产业的坏人。本章也是打回 老家，故名。) (translated by Sun Fali, p212-213)

The addition of the annotation provides the children readers with enough cultural information, and therefore the children can understand the novel much better.

The translations which are chosen accurately and translated appropriately can offer a good chance for children to have acquaintance with the foreign cultures and enlarge their knowledge. Anyhow, the translations should not confuse the children. To some extent, the reappearance of the foreign cultures and linguistic features can be reached by the harmony and unity between the language and individuality.

\section{CONCLUSION}

As can be seen from the above, every period has its own characteristics in terms of the translation of the children's literature, and what most of the translators keep in mind is that the translation of the children's literature should be based on the special cognition and understanding characteristics of the children, and children's acceptance should be taken into consideration. Most of the translators know clearly that they are translating for the children and that the translation of the children's literature is different from that of the adults. Nowadays there are more and more foreign works translated into China, in which case the Chinese children are becoming international. The translated versions of the children's literature provide Chinese children with good literature, broaden the horizon of the children's vision and 
promote the development of the Chinese children's literature.

\section{REFERENCES}

[1] Chen Fu'an. (1981). Alice's Adventures in Wonderland. China Translation \& Publishing Corporation.

[2] Jia Wenhao, Jia Wenyuan. (2006). Alice's Adventures in Wonderland. Beijing: Yanshan Publishing House.

[3] Qin Gong. (2004). Characteristics of the Translation of Children's Literature during May Fourth Period. Journal of Graduate School of Chinese Academy of Social Sciences, 4 p114-118

[4] Ren Rongrong. (2008). Charlotte's Web. Shanghai Translation Publishing House.

[5] Ren Rongrong. (2008).The Wind in the Willows. Juvenile and Children's Publishing House.

[6] Shavit, Zohar, (1981). Translation of Children's Literature as a Function of Its Position in the Literary Polysystem. Poetics Today.

[7] Sun Fali. (2002).The Wind in the Willows. Anhui: Literature and Art Publishing House.

[8] Wen Jun, Wang Chenshuang. (2008). Translation of Children's Literature during the Sino-Japanese War. Comparative Literature in China, 4, p11.

[9] Wu Juntao. (2008). Alice's Adventures in Wonderland. Shanghai Translation Publishing House.

[10] ZhaoYuanren. (2004). Alice's Adventures in Wonderland. China Translation \& Publishing Corporation.

Yu Zhang was born in Baishan, China in 1965. She received her M. A. degree in linguistics from Dalian Maritime University, China in 1999.

She is currently an associate professor in the School of Foreign Languages, Qingdao University of Science and Technology, Qingdao, China. Her research interests include translation theory and practice. 